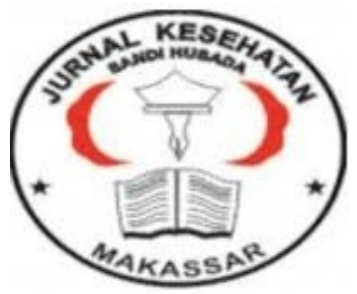

\author{
Jurnal Ilmiah Kesehatan Sandi Husada \\ hhttps://akper-sandikarsa.e-journal.id/ЈIKSH
}

Vol 11, No, 1, Juni 2020, pp;334-340

p-ISSN: 2354-6093 dan e-ISSN: 2654-4563

DOI: $10.35816 /$ jiskh.v10i2.283

\title{
Potensi Batang Pisang (Musa Pardisiaca L.) Dalam Penyembuhan Luka Bakar
}

Banana Stem Potency in Burn Wound Healing

Gusti Agung Putu Yogy Veda Ananta ${ }^{1}$

${ }^{1}$ Pendidikan Dokter, Universitas Lampung

\begin{tabular}{l}
\hline \multicolumn{1}{c}{ Artikel info } \\
\hline Artikel history: \\
Received; 18 April 2020 \\
Revised: 19 April 2020 \\
Accepted;23 April 2020
\end{tabular}

\begin{abstract}
Abstrak.
Luka bakar timbul sebagai respon lokal dari suatu jaringan, dengan atau tanpa respon sistemik terhadap transfer energi dari sumber fisika (mekanik, termal, radiasi, elektrik) maupun sumber kimia. Dampak yang ada, merugikan bagi manusia baik secara psikologis maupun secara fisik. Hal ini dikarenakan luka jenis ini termasuk salah satu trauma dengan bentuk paling parah yang membuat manusia menderita dari periode lampau dan selama bertahun tahun peneliti melakukan uji coba demi mendapatkan perbaikan pada hasil akhir rangkaian perawatan kejadian luka bakar. Saat ini, ragam tanaman di Indonesia belum banyak diketahui memliki khasiat dalam berbagai hal dibidang kesehatan. Pisang (Musa paradisiaca L.) memiliki khasiat dalam menyembuhkan luka. Hasil penelitian sebelumnya menggunakan luka sayat, menunjukan bahwa ekstrak batang pohon pisang mengandung tanin, saponin, dan flavonoid, dimana masing masing zat tersebut mempunyai peran dalam proses menyembuhkan luka. Saponin, senyawa ini memiliki aktivitas antiseptik yang membantu dalam proses penyembuhan luka. Flavonoid dari golongan flavonol, flavon, dan isoflavon memiliki aktivitas anti inflamasi. Tanin adalah senyawa polifenol dari keloimpok flavonoid yang berfungsi sebagai antioksidan kuat dan juga anti inflamasi.
\end{abstract}

\begin{abstract}
.
Burn wounds appear as local response from tissue, with or without systemic response to energy transfer from physics source (mechanic, thermal, radiation, electricity) or chemical source. The impact are detrimental psycologically or physically to human. It is because this type of wound included in worst shaped-trauma that made human suffer since long ago and many years researcher did some trial to get improvement on burn wounds outcome from the series of treatment. This time, many plants in Indonesia not yet known
\end{abstract}


to have efficacy in health. Banana (Musa paradisiaca L.) have a savor in wound healing. The result from previous research, showed that the banana stem extract contain of tannin, saponin, and flavonoid, which each of them have their own role in wound healing process. Saponin, this compound have antiseptic activity that help in wound healing. Flavonoid from flavonol, flavon, and isoflavon group have anti-inflammatory activity. Tanin is a polyphenols compound from flavonoid group that have function as a powerful antioxidant and also anti-inflammatory.

Keywords:

Ekstrak Batang

Pisang;

Flavonoid;

Luka bakar;
Coresponden author:

Email: vedayogy@gmail.com

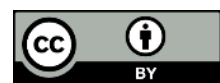

artikel dengan akses terbuka dibawah lisensi CC BY -4.0

\section{Pendahuluan}

Luka bakar merupakan respon lokal dari suatu jaringan, dengan atau tanpa respon sistemik terhadap transfer energi dari sumber fisika (mekanik, termal, radiasi, elektrik) maupun sumber kimia (Koller, 2014). Luka bakar sering menimbulkan dampak yang merugikan bagi manusia baik secara psikologis maupun secara fisik. Hal ini dikarenakan luka jenis ini termasuk trauma dengan bentuk parah yang membuat manusia menderita sejak zaman dahulu (Garcia-Espinoza, Aguilar-Aragon, 2017).

Kematian di dunia yang disebabkan oleh luka bakar, didapatkan sekitar 265.000. Lebih dari 96\% kejadian luka bakar terjadi di negara dengan pendapatan rendah dan menengah dengan berjuta korban menderita disabilitas jangka panjang, kecacatan, sering menghasilkan penolakan di masyarakat dan juga stigma (Sminkey, 2020). Pada kulit, luka bakar dapat menyebabkan rusaknya kulit dan mengganggu fungsi termoregulatorik, sensorik, protektif, metabolik dan sinyal seksual dari kulit (Tortora \& Derrickson, 2014). Kejadian ini termasuk salah satu trauma dengan bentuk paling parah yang membuat manusia menderita dari periode lampau dan selama bertahun tahun peneliti melakukan uji coba demi mendapatkan perbaikan pada hasil akhir rangkaian perawatan kejadian luka bakar (Sminkey, 2020).

Luka bakar diklasifikasikan pada banyak penentu, salah satunya berdasarkan pada dalamnya trauma pada lapisan kulit yaitu luka bakar derajat 1 (superficial burns), derajat 2 (partial thickness burn), dan derajat 3 (full thickness burn). Proses penyembuhan luka bakar bergantung terhadap kedalaman trauma, yang meliputi proses inflamasi, proliferasi, dan proses pematangan atau remodeling (Tivari, 2012). Luka bakar tampak menjadi sebuah masalah serius apabila tidak bias ditangani dengan tepat. Saat ini, ragam tanaman di Indonesia belum banyak diketahui memliki khasiat dalam berbagai hal dibidang kesehatan. Salah satu tanaman, yaitu Pisang (Musa paradisiaca L.) memiliki khasiat dalam menyembuhkan luka. Pisang merupakan salah satu dari berbagai macam buah yang ada di Indonesia. Penyebaran buah pisang di dunia telah diketahui sebanyak 1000 kultivar pisang dan saat ini kurang lebih 200 kultivar telah teridentifikasi di Indonesia. Data menunjukkan pada tahun 2016 terdapat 397.700 pohon pisang di Indonesia. Provinsi Lampung memegang urutan kedua setelah Jawa Barat dengan jumlah 40.000 pohon setara dengan Jawa Tengah (Sholikhah, Bonavia, 2017). Pisang juga diyakini sebagai buah yang 
kaya nutrisi juga kaya akan manfaat di bidang kesehatan lainnya. Bunga yang memiliki kelebihan sebagai makanan pada diet penderita diabetes, getahnya yang memiliki kemampuan untuk menyembuhkan luka dan meredekan gigitan serangga, akarnya yang memiliki kemampuan untuk mengobati masalah di saluran pencernaan (Umadevi, 2012).

\section{Metode}

Penelitian ini menggunakan studi literature review, dengan peneliti yang berperan mencari dan menggabungkan inti sari serta menganalisis fakta dari sumber ilmiah yang sesuai kriteria valid dan akurat. Studi literatur menyajikan kembali materi yang diterbitkan sebelumnya, dan melaporkan fakta atau analisis baru. Tinjauan literature menyajikan ringkasan berupa publikasi paling relevan kemudian membandingkan hasil yang disajikan dalam makalah.

\section{Hasil Dan Pembahasan}

Pohon pisang adalah salah satu pohon dengan buah yang memiliki kandungan karbohidrat kompleks. Selain buah, batang dan akar pohon pisang pun memiliki kandungan yang bermanfaat dalam kehidupan manusia sehari - hari, khususnya dalam bidang kesehatan.

Tanaman pisang memliki taksonomi sebagai berikut.

$\begin{array}{lll}\text { Divisi } & : & \text { Magnoliphyta } \\ \text { Sub Divis } & : & \text { Spermatophyta } \\ \text { Kelas } & : & \text { Liliopsyda } \\ \text { Sub Kelas } & : & \text { Commenlinidae } \\ \text { Ordo } & : & \text { Zingiberales } \\ \text { Famili } & : & \text { Musaceae } \\ \text { Genus } & : & \text { Musa } \\ \text { Spesies } & : & \text { Musa paradisiaca var. sapientum(L.) }\end{array}$

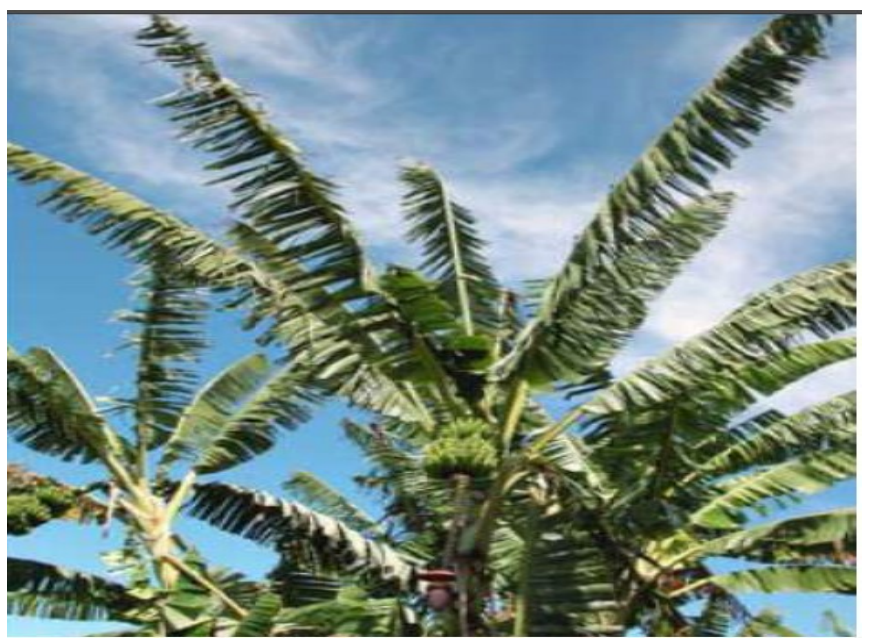

Gambar 1. Tanaman Pisang (Musa paradisiaca L)

(Laksari, 2017).

Ekstrak batang pohon pisang mengandung tanin, saponin, dan flavonoid. Saponin mempunyai sifat sama dengan glikosida, menghasilkan buih apabila dimasukkan dalam air. 


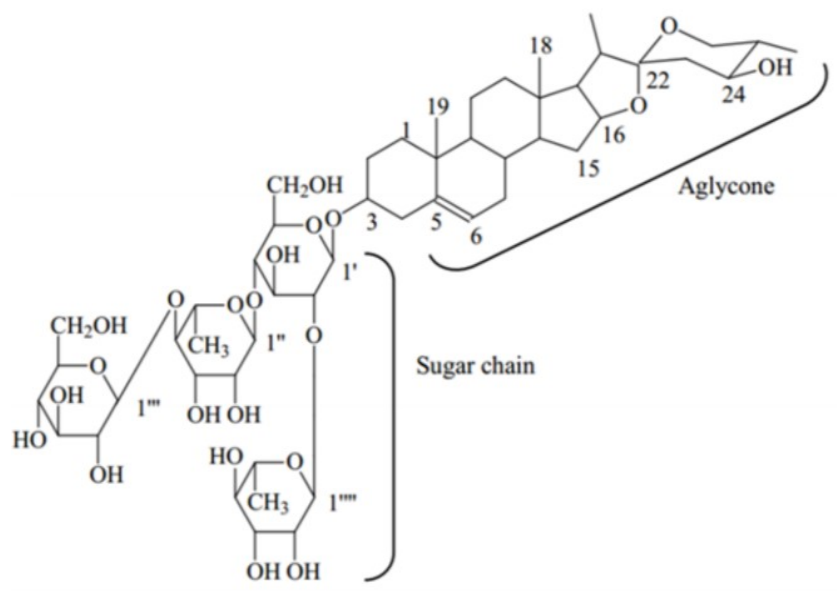

Gambar 2. Saponin

(Aziz, 2019)

Senyawa ini sangat polar sehingga sulit untuk diisolasi, tetapi menariknya senyawa ini memiliki bioaktivitas tinggi. Senyawa ini juga memiliki aktivitas antibiotik yang membantu dalam proses penyembuhan luka, dimana tegangan permukaan sel dari bakteri menurun yang akan meningkatkan permeabilitas sehingga komponen intraseluler keluar karena kebocoran sel (Apriasari Maharani Laillyza, Fadhilah ahmad, Amy N Cerebelly, 2013; Nuria, 2009). Flavonoid merupakan senyawa polifenol, yaitu satu golongan fenol alam yang terbesar dan bersifat polar sehingga mudah larut dalam pelarut polar seperti air, etanol, butanol, methanol, dan aseton. Flavonoid umumnya ditemukan dalam bentuk glikosida yang larut air. Flavonoid dari golongan flavonol, flavon, dan isoflavon memiliki aktivitas anti inflamasi. Hal ini dibuktikan dengan energi ikatan flavonoid pada situs siklooksigenase yaitu $-8.77 \mathrm{kcal} / \mathrm{mol}$ hingga $6.24 \mathrm{kcal} / \mathrm{mol}$ yang tidak berbeda jauh jika dibanding standar Celecoxib $(-8.30 \mathrm{kcal} / \mathrm{mol})$ (Madeswaran, 2012). Flavonoid sebagai anti-inflamasi bekerja dengan cara memproduksi pro inflamatori mediator menstimulasi sel yang berkaitan dengan inflamasi seperti limfosit, monosit,natural killer sel, neutrophil, makrofag, dan sel mastos ${ }^{i+}$<smiles>[c-]1cccc(C2CCc3ccccc3O2)c1</smiles>

(Panche, 2016)

Senyawa lainnya yaitu tanin, merupakan senyawa polifenol dari kelompok flavonoid yang berfungsi sebagai antioksidan kuat dan juga anti inflamasi. Tanin juga memiliki efek utama kosmetika mengencangkan kulit. Selain itu, senyawa ini membentuk lapisan pelindung bagi jaringan yang terkait sehingga mencegah nya terinfeksi kembali (Ashook, 2012). 
<smiles></smiles>

Gambar 4. Tanin

(Huang Q, 2018)

Salah satu bagian tubuh manusia yang terpapar luka bakar yaitu kulit. Kulit sendiri memiliki 3 lapis, yaitu epidermis, dermis dan subkutan. Lapisan epidermis adalah lapisan kulit pertama yang berhubungan langsung dengan dunia luar (Mescher, 2016). Dermis adalah jaringan ikat yang menunjang epidermis dan mengikatnya pada jaringan subkutan (hipodermis). Pembuluh darah, serabut saraf, kelenjar, dan folikel rambut tertanam pada lapisan dermis (Mescher, 2016; Tortora \& Derrickson, 2014). Lapisan ini tersusun atas jaringan ikat longgar yang berikatan dengan kulit secara longgar pada organ-organ dibawahnya. Dengan begini memungkinkan kulit bergeser diatasnya (Mescher, 2016). Kedalaman pada luka bakar ditentukan oleh banyak faktor, terutama besar temperatur, luas trauma, dan lamanya kontak dengan sumber (Robbins, 2007).

Proses penyembuhan akibat luka bakar memiliki variasi sesuai dengan klasifikasi berdasarkan kedalaman luka bakar. Pada luka bakar proses penyembuhan luka meliputi 4 fase yaitu, fase hemostasis, fase inflamasi , fase proliferasi dan fase remodeling (Sinno, 2013). Fase Hemostasis adalah kemampuan tubuh untuk menghentikan perdarahan pada saat terjadi trauma dan mencegah terjadinya perdarahan spontan yang berkelanjutan. Plak trombosit yang ada dari fase hemostasis akan melepaskan kemotraktan berupa sitokin proinflamasi dan growth factor seperti Transforming Growth Factor (TGF-B), Platelet-Derived Growth Factor (PDGF), Fibroblast Growth Factor (FGF), dan Epidermal Growth Factor (EGF) yang akan menarik sel radang, sel endotel, dan fibroblas yang ada di sekitar daerah luka (Rowan, 2015).

Beralih ke fase Inflamasi atau peradangan, fase ini merupakan suatu respon perlindungan oleh jaringan untuk mengeradikasi mikroorganisme penyebab jejas atau membuang sel dan jaringan nekrotik yang disebabkan oleh kerusakan sel. Setelah fase hemostastis selesai, pelepasan histamin yang diinisasi oleh pengaktifkan kaskade komplemen akan menyebabkan vasodilatasi pembuluh darah kapiler yang menigkatkan aliran darah dan perubahan permeabilitas kapiler mempermudah migrasi sel radang menuju daerah luka. Dimana selanjutnya netrofil akan menuju daerah luka lalu membersihkan luka dengan melepas mediator sitotoksik. Pada tahap selanjutnya bakteri dan debris tesebut akan difagosit oleh makrofag. Makrofag melakukan fagositosis terhadap debris dan bakteri, sulit untuk mensekresi growth factor guna produksi matriks ekstraseluler oleh fibroblast dan produksi dari pembuluh darah baru. Hal ini nantinya yang akan menjadi sesuatu yang penting bagi fase penyembuhan luka berikutnya yaitu fase proliferasi (Prasetyono, 2009) 
Pada fase proliferasi terdapat dua proses penting yang berjalan secara bersaaman yaitu proses angiogenesis (pembentukan pembuluh kapiler baru) dan penutupan luka bakar yang meliputi re-epitelisasi, pembentukan jaringan granulasi, dan deposisi kolagen pada daerah luka. Selama fase proliferasi bagian kulit yang mengalami luka akan dipenuhi oleh sel radang, fibroblas, dan kolagen yang akan membentuk suatu jaringan berwarna kemerahan mengandung pembuluh darah pada dasar luka yang disebut jaringan granula (Sinno, 2013)

Selanjutnya fase terakhir yaitu fase remodeling. Tahap ini merupakan fase pematangan luka yang terdiri atas penyerapan sel-sel radang, pembentukan kolagen lanjut, penutupan dan penyerapan kembali pembuluh darah baru, pengerutan luka, dan pemecahan kolagen berlebih. Fase ini dimulai sejak akhir fase proliferasi dan dapat berlangsung hingga berbulan-bulan. Pada fase ini luka akan mengalami proses maturasi dengan serat kolagen dan elastin yang secara terus menerus akan disimpan dan dibentuk kembali bersamaan dengan perubahan fibroblas menjadi miofibroblas (Rowan, 2015; Sinno, 2013).

Berdasarkan penelitian percobaan oleh pongsipulung dan prasetyo dengan subjek penelitian tikus dan mencit, ektrak batang pohon pisang memiliki efek yang cukup baik terhadap luka yang dibuat (luka sayat) oleh peneliti (Pongsipulung, Yamlean, Banne, 2012; Prasetyo, 2012). Hasil penelitian menunjukkan bahwasanya sediaan ekstrak batang pohon pisang yang diberikan mengandung zat aktif yang meningkatkan aliran darah menuju daerah luka dan dapat menstimulasi fibroblast sebagai respon untuk penyembuhan luka. Diketahui bahwa dalam penyembuhan luka, terdapat banyak faktor yang akan berdampak pada proses pemulihan. Faktor ini berupa infeksi, jenis jaringan yang mengalami jejas, lokasi (sifat jaringan yang mengalami jejas), penyimpangan pertumbuhan sel dan produksi matriks ekstraseluler, serta mekanisme dari fibrosis yang pada dasarnya tak jauh beda dengan mekanisme penyembuhan luka lainnya (Robbins, Stanley L, Cotran, Ramzi S, Kumar, Vinay, 2007). Oleh karena itu, apabila dalam kondisi serupa, dimana batasan luka sesuai antara luka bakar dengan luka sayat, luka bakar mempunyai peluang yang sama untuk disembuhkan dengan menggunakan ekstrak batang pohon pisang.

\section{Simpulan Dan Saran}

Ekstrak batang pohon pisang memiliki potensi dalam proses penyembuhan luka bakar yaitu sebagai anti inflamasi, antibiotik dan memiliki efek antioksidan kuat yang akan membantu dalam proses penyembuhan luka bakar.

\section{Daftar Rujukan}

Apriasari ML, Fadhilah A, Carabelly AN. Aktivitas Antibakteri Ekstrak Etanol Batang Pisang Mauli (Musa sp.) terhadap Streptococcus mutant. Jurnal Dentofasial. 2013; 12(3):148-151.

Ashok PK, Upadhyaya K. Tannins are Astringent. Journal of Pharmacognosy and Phytochemistry. 2012; 1(3): 45-50.

Aziz MMAE, Ashour AS, Melad ASG. A Review On Saponins From Medicinal Plants: Chemistry,Isolation, And Determination. Journal of Nanomedicine Research. 2019; 7(4).

Garcia-Espinoza J, Aguilar-Aragon V, et. al. Burns: Definition, Classification, Pathophysiology and Initial Approach. Omi Int. 2017;5(5). 
Huang Q, Liu X, Zhao G, Hu T, Wang Y. Potential and Challenges Of Tannins as An Alternative To In-Feed Antibiotics for Farm Animal Production. Animal nutrition (Zhongguo xu mu shou yi xue hui). 2018;4(2): 137-150.

Koller J. Burns Textbook for Students of General Medicine and Dentistry. 1st ed. Laca L, editor. Bratislava: Comenius University Bratislava; 2014: 5-9.

Laksari VN. Uji Aktivitas Ekstrak Etanol Kulit Buah Pisang Ambon (Musa paradisiaca var.sapientum (L.) Kunt) Pada Tikus Putih Dengan Induksi Glukosa. Skripsi. 2017;91:399-404.

Madeswaran A, Umamaheswari M, Assokumar K, Sivashanmugam T, Subhadradevi V, Jagannath P. Docking Studies: In Silico Phosphodiesterase Inhibitory Activity Of Commercially Available Flavonoids. Bangladesh J Pharmacol. 2012; 7:70-75

Mescher AL. Histologi Dasar JUNQUEIRA. Edisi 12. Hartanto H, editor. Jakarta: EGC; 2016.

Nuria MC, Faizatun A, Sumantri. UJI aktivitas antibakteri ekstrak etanol daun jarak pagar (Jatropha curcas L) terhadap bakteri Staphylococcus aureus ATCC 25923, Escherichia coli ATCC 25922, dan Salmonella typhi ATCC 1408. Mediagro. 2009; 5(2):26-37.

Panche, A. N., Diwan, A. D., \& Chandra, S. R. Flavonoids: an overview. Journal of nutritional science. 2016; 5.(47).

Pongsipulung G. R., Yamlean P. V. Y, \& Banne Y. Formulasi dan Pengujian Salep Ekstrak Bonggol Pisang ( Musa paradisiaca var. Sapientum ) Terbuka Pada Kulit Tikus Putih Jantan Galur Wistar. Pharmacon. 2012;1(2):7-13.

Prasetyo, B. F. Aktivitas dan uji stabilitas sediaan gel ekstrak batang pisang ambon (Musa paradisiaca var sapientum) dalam proses persembuhan luka pada mencit (mus musculus albinus); 2012.

Prasetyono, O.H.T. General Concept of Wound Healing. Medical Journal of Indonesia. 2009; 18(3):208-16.

Robbins, Stanley L, Cotran, Ramzi S, Kumar, Vinay. Buku Ajar Patologi. Jakarta: EGC; 2007.

Rowan MP, Cancio LC, Elster EA, Burmeister DM, Rose LF, Natesan S. Burn wound healing and treatment: Review and advancements. Crit Care. 2015;19(1):1-12.

Sholikhah SN, Bonavia VS. Statistik Pertanian 2017. Susanti AA, Waryanto B, editors. Jakarta: Pusat Data dan Sistem Informasi Pertanian Kementrian Pertanian Republik Indonesia; 2017.

Sinno H, Prakash S. Complements and the Wound Healing Cascade: An Updated Review. Plast Surg Int. 2013;1-7.

Sminkey, L. Burns. disadur 18 April, 2020, dari World Health Organitation website:https://www. who.int/violence_injury_prevention/other_injury/burns/en

Tiwari, V K. Burn wound: How it differs from other wounds?. Indian journal of plastic surgery. 2012;45(02):364-373.

Tortora GJ, Derrickson B. Principles of Anatomy \& Physiology. 14th ed. Wiley. United States of America: John Wiley \& Sons, Inc. 2014; 886-979.

Umadevi M, Rajeswari R, Rahale C, Selvavenkadesh S, Pushpa R, Kumar K. Traditional and Medicinal Uses of Withania somnifera. Pharma Innov. 2012;1(9):102-10. 